\title{
VARIABILITY OF WATER BALANCE COMPONENTS IN A COFFEE CROP IN BRAZIL
}

\author{
Adriana Lúcia da Silva ${ }^{1}$; Renato Roveratti ${ }^{1}$; Klaus Reichardt ${ }^{1 *}$; Osny Oliveira Santos Bacchi ${ }^{1}$; \\ Luis Carlos Timm²; Isabeli Pereira Bruno4; Julio César Martins Oliveira ${ }^{3}$; Durval Dourado \\ $\mathrm{Neto}^{4}$ \\ ${ }^{1}$ USP/CENA - Lab. de Física do Solo, C.P. 96 - 13400-970 - Piracicaba, SP - Brasil. \\ ${ }^{2}$ UFPel - Depto. de Engenharia Rural, C.P. 354 - 96001-970 - Pelotas, RS - Brasil. \\ ${ }^{3}$ EEP - Av. Monsenhor Martinho Salgot, 560 - 13414-400 - Piracicaba, SP - Brasil. \\ ${ }^{4}$ USP/ESALQ - Depto. de Produção Vegetal, C.P. 9 - 13418-970 - Piracicaba, SP -Brasil. \\ *Corresponding author <klaus@cena.usp.br>
}

\begin{abstract}
Establishing field water balances is difficult and costly, the variability of their components being the major problem to obtain reliable results. This component variability is presented herein for a coffee crop grown in the Southern Hemisphere, on a tropical soil with $10 \%$ slope. It was observed that: rainfall has to be measured with an appropriate number of replicates; irrigation can introduce great variability into calculations; evapotranspiration, calculated as a remainder of the water balance equation, has exceedingly high coefficients of variation; the soil water storage component is the major contributor in error propagation calculations to estimate evapotranspiration; and that runoff can be satisfactorily controlled on the $10 \%$ slope through crop management practices.
\end{abstract}

Key words: component variability, rainfall, evapotranspiration, soil water storage

\section{VARIABILIDADE DOS COMPONENTES DO BALANÇO HÍDRICO DE UMA CULTURA DE CAFÉ NO BRASIL}

\begin{abstract}
RESUMO: O estabelecimento de balanços hídricos no campo é difícil e dispendioso, sendo a variabilidade de seus componentes o maior problema para se obter resultados confiáveis. Esta variabilidade dos componentes é aqui apresentada para uma cultura de café desenvolvida no hemisfério sul, em um solo tropical com $10 \%$ de declividade. Foi observado que a chuva deve ser medida com número apropriado de repetições; a irrigação pode introduzir grande variabilidade dos cálculos; a evapotranspiração calculada a partir da equação do balanço hídrico tem coeficientes de variação muito altos; o componente armazenamento de água no solo é o que mais contribui na propagação dos erros; e que a enxurrada pode ser satisfatoriamente controlada nesse declive de $10 \%$ por meio de práticas de manejo.

Palavras-chave: variabilidade dos componentes, chuva, evapotranspiração, armazenamento de água
\end{abstract}

\section{INTRODUCTION}

Water balances are important to follow water dynamics in agricultural and natural ecosystems. They indicate, in space and time, conditions under which plants grow and develop, and are useful in the interpretation of plant behavior during periods that differ from the ordinary local climatic conditions, such as periods of water excess or deficit. These aspects are important for crop management and the understanding of the behavior of natural ecosystems. The lack of response of a crop to a fertilizer, or the disappearance of a given natural species, can be partially explained in the light of consistent water balances (Pereira et al., 2002).

Coffee farming is one of the most important agribusiness in Brazil, comprising almost 3 million ha planted area, with a production of 34 million, $60-\mathrm{kg}$ bags of dry beans per year (FNP Consultoria \& Comércio, 2004). Among factors that affect coffee productivity are the water relations in the soil-plant-atmosphere system and the availability of nutrients, mainly nitrogen (Gregorich \& Carter, 1997; Monteith, 1973). The establishment of water balances is an excellent tool to better understand these water relations with respect to the growth and development of the crop, and to quantify important nitrogen losses by leaching, volatilization and runoff.

Because of the required equipment, establishing field water balances is time consuming and costly. Therefore, they are rarely replicated to obtain significant average values. Since the water balance is an addition of several components, each of them having its own space and time variability, error propagation can 
lead to inconsistent results. Villagra et al. (1995) discuss this variability problem in a study comprising 25 balance replicates, their main problem being the estimation of soil water fluxes below the rootzone. This work discusses the variability of field water balance components in a 0.2 ha coffee crop.

\section{MATERIAL AND METHODS}

\section{Experimental Fiel d}

The experiment was carried out in Piracicaba, SP, Brazil, $\left(22^{\circ} 42^{\prime} \mathrm{S}, 47^{\circ} 38^{\prime} \mathrm{W}\right.$, altitude $\left.580 \mathrm{~m}\right)$ on a Rhodic Kandiudalf, locally "Nitossolo Vermelho Eutroférrico" (Embrapa, 1999) with moderate A horizon, clayey texture profile ( $29 \%$ sand, $16 \%$ silt, and $55 \%$ clay); $\mathrm{pH} 5.5 ; 25 \mathrm{~kg} \mathrm{~m}^{-3}$ of organic matter. Local climate is Cwa (Köppen's), mesothermic; dry winter with average temperature during the coldest month below $18^{\circ} \mathrm{C}$ and during the warmest month superior to $22^{\circ} \mathrm{C}$. Annual average temperatures, rainfall, and relative humidity are, respectively, $21.1^{\circ} \mathrm{C}, 1,257 \mathrm{~mm}$, and $74 \%$. The dry season goes from April to September; July being the driest month; January and February are the wettest. Rainfall during the driest month do not exceed $30 \mathrm{~mm}$ (Villa Nova, 1989). Figure 1 presents an ombrothermic diagram of Piracicaba, built with 87-year averages.

Coffee plants (Coffea arabica L.), cultivar "Catuaí Vermelho" (IAC-44) were planted in line along contour lines in May 2001, spaced $1.75 \mathrm{~m}$ between rows and $0.75 \mathrm{~m}$ between plants. The 0.2 -ha planted area was divided into 15 plots, 120 plants each. Evaluations started September $1^{\text {st }}, 2003$ at $8 \mathrm{~h} 00$. Because coffee is a perennial crop, the following evaluation dates received the code days after beginning - DAB followed by the number of days. A field day started and finished at $8 \mathrm{~h} 00$ of successive days.

The five replicates used to establish the water balances, made in isolated, fenced sub-plots with nine plants, covered an area of $11.8 \mathrm{~m}^{2}, 10 \pm 2 \%$ slope, and received $280 \mathrm{~kg} \mathrm{ha}^{-1} \mathrm{~N}$ (enriched ammonium sulphate)

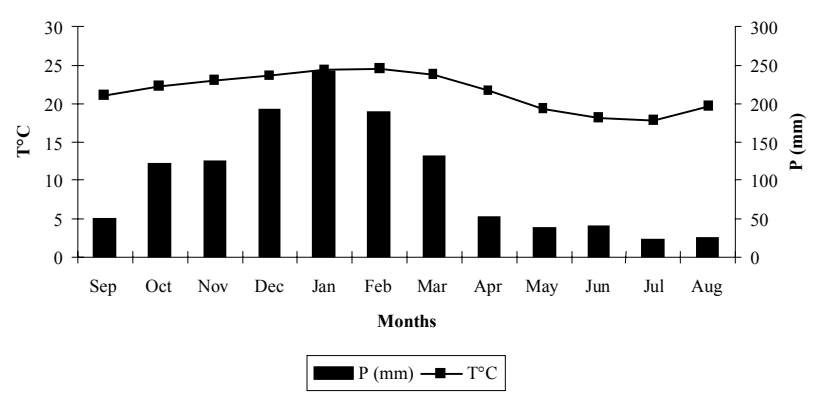

Figure 1 - Ombrothermic diagram of Piracicaba starting in September to cover the coffee-plant annual cycle, from flowering to fruit maturation. in four applications (DAB-0, DAB-63, DAB-105, and DAB-151) plus ordinary $P$ and $K$ fertilization. The experimental area is located in the edge of a central-pivot irrigation system, so regular applications of water depths are not possible. An automatic meteorological station (CR21X, Campbell Scientific, Logan, Utah, EUA) was installed $200 \mathrm{~m}$ from the plot to record solar radiation (radiometer model Q7.1 - Radiation Energy Balance Systems Inc., Seattle, Washington, EUA); wind speed and direction (sensor model 03001 Wind Sentry anemometer and Vane, R. M. Young, Traverse City, Michigam EUA); soil heat flux (sensor model HFT3, Rebs, Seattle, Washington, EUA); air temperature and humidity (sensor model HTM45C, Vaisala, Helsink, Finland); global radiation (sensor model LI200, Li-Cor, Lincoln, Nebraska USA); and rain gauge (model TE525, Texas Eletronics Inc., Dallas,Texas, EUA).

\section{Water Balance}

Water balances started on September $1^{\text {st }}, 2003$ (DAB-0) and continued for 14 day periods $\left(\Delta t=t_{i+14^{-}}\right.$ $t_{i}$ ), sequentially, until August 30, 2004 (DAB-364). The classical water balance equation representing the mass conservation law was used, considering water flux densities entering and leaving a soil volume element of 1 $\mathrm{m}$ depth, integrated over time:

$\int_{t_{i}}^{t_{i+14}} p d t+\int_{t_{i}}^{t_{i+14}} i d t-\int_{t_{i}}^{t_{i+14}} e d t-\int_{t_{i}}^{t_{i+14}} r d t \pm \int_{t_{i}}^{t_{i+14}} q_{L} d t+S_{i+14}-S_{i}=0$

which, by solving the integrals, results in:

$\mathrm{P}+\mathrm{I}-\mathrm{ER}-\mathrm{RO}-\mathrm{Q}_{\mathrm{L}}+\Delta \mathrm{S}=0$

where $\mathrm{P}=$ rainfall; $\mathrm{I}=$ irrigation; $\mathrm{ER}=$ actual evapotranspiration; $\Delta \mathrm{S}=\mathrm{S}_{\mathrm{i}+14}-\mathrm{S}_{\mathrm{i}}=$ soil water storage changes in the soil $0-\mathrm{L}$ layer; $\mathrm{RO}=$ runoff; and $\mathrm{Q}_{\mathrm{L}}=$ deep drainage at the lower boundary of the soil volume at the depth $\mathrm{z}=\mathrm{L}$, all expressed in $\mathrm{mm}$.

Rainfall (P) was measured daily and integrated over $\Delta \mathrm{t}$ at each replicate, using traditional rain-gauges ("Ville de Paris") with $404.7 \mathrm{~cm}^{2}$ collecting areas, installed in the sub-plots $1.2 \mathrm{~m}$ above soil surface. Because of neighboring obstacles, such as a silo, a warehouse, orchards, and tall trees, the rainfall was not taken at the automated station, but measured at each of the five replicates of the plot using five rain-gauges, enabling to obtain average values $(\bar{P})$ with standard deviations $[\mathrm{s}(\mathrm{P})]$ and coefficients of variation $(\mathrm{CV})$, which were compared to the readings of the automated station.

The region's coffee farmers adopt supplementary irrigation, and only during severe drought periods, and this standard practice was carried out during the 
study. As mentioned, the studied plots bordered a center-pivot irrigation system; therefore water application was subjected to some variability. This variable was also measured by the five rain-gauges installed for rainfall measurement.

Criteria for amount and time of irrigation were mostly based on the physiology of coffee plants, which require a cold and dry winter to blossom, starting after the first significant rain. After blossoming, excessive water shortage may cause flower loss. Therefore, the decision to irrigate was taken upon visual observation of the plants in relation to water deficit; applications of $30 \mathrm{~mm}$ of water depth, that approximately would wet a $0.6 \mathrm{~m}$ soil layer, were attempted. A more technical criterion to judge the water deficit, e.g. estimating water availability through soil water content/ potential measurements, was not introduced in the planning of the experiment because the region lies within a favorable coffee crop zone.

The actual crop evapotranspiration (ER) was estimated as a remainder in equation (2). In wet periods, with drainage $\left(\mathrm{Q}_{\mathrm{L}}\right)$ likely to happen and considering it as zero in equation (2), ER, now named ER', was overestimated including $\mathrm{Q}_{\mathrm{L}}$. In these periods, ER was larger than the potential evapotranspiration (ET), and the difference ER-ET $=\mathrm{Q}_{\mathrm{L}}$. The potential evapotranspiration was estimated from the reference evapotranspiration $\left(\mathrm{ET}_{0}\right)$, corrected by the crop coefficient $\left(\mathrm{K}_{\mathrm{C}}\right) . \mathrm{ET}_{0}$ was calculated using Penman-Monteith equation (Pereira et al., 1997), with meteorological data collected at the automatic weather station. $\mathrm{K}_{C}$ was calculated by dividing $\mathrm{ER}=\mathrm{ET}$ by $\mathrm{ET}_{0}$ along the periods in which plants were not under stress, i.e., when the soil water storage was relatively high and without drainage. The above referred $\mathrm{K}_{\mathrm{C}}$ was the average value obtained for these periods.

Since ER was calculated from the balance equation (2), its variability was estimated through error propagation:

$s^{2}\left(E R^{\prime}\right)=s^{2}(P)+s^{2}(I)+s^{2}(R O)+s^{2}\left(S_{i+14}\right)+s^{2}(S)$

and $s\left(Q_{L}\right)$ was taken equal to $s\left(E R^{\prime}\right)$ since it was calculated by the difference ER'-ET, considering ET an absolute value.

The soil layer $0-1 \mathrm{~m}(\mathrm{~L}=1 \mathrm{~m})$ was chosen to calculate soil water storages $S\left(t_{i}\right)$ once at this stage of the crop, this soil layer contained more than $98 \%$ of the root system. $S\left(t_{i}\right)$ was estimated from volumetric soil water content measurements $\left(\theta, \mathrm{m}^{3} \mathrm{~m}^{-3}\right)$ obtained by a neutron probe, using three access tubes installed down to the depth of $1.2 \mathrm{~m}$ in each plot, making up a total of 15 tubes. The calibration of this probe, model CPN 503 DR, was made in an area close to the experimental field, as described by Basanta (2004). The moisture contents were measured at depths of 0.20 , $0.40,0.60,0.80$, and $1.00 \mathrm{~m}$, at the selected dates $\mathrm{t}$ during the experimental period, which started at $t_{i}$ (DAB-0) and continued up to $\mathrm{t}_{\mathrm{i}+14}, \Delta \mathrm{t}=14$ days. $S\left(t_{i}\right)$ was calculated using the trapezoidal rule:

$S\left(t_{i}\right)=\int_{0}^{L} \theta\left(t_{i}\right) d z=\left[\bar{\theta}\left(t_{i}\right)\right] . L$

where $\bar{\theta}\left(t_{i}\right)$ is the average $\theta$ at time $t_{i}$ and the soil depth $\mathrm{L}$, in this case taken as $1,000 \mathrm{~mm}$ in order to obtain $\mathrm{S}$ expressed in $\mathrm{mm}$. Finally, to measure runoff, each plot was framed by metal floodgates, and the water was collected by gravity in 200-L tanks placed down the slope.

\section{RESULTS AND DISCUSSION}

\section{Rainfall (P)}

Accumulated values of $\mathrm{P}$ for each water balance period are presented in Table 1. Despite raingauges being relatively near to each other (15 to 100 $\mathrm{m}$ apart), there was significant variability among the readings performed on the five replicates. Although low CV values were recorded $(2-4 \%)$, CV records for water balances 2,16 , and 22 , exceeded $10 \%$. For balances 2 and 22 this can be explained by the low amounts of rainfall; for balance 16 an unexplained outlayer of $78.6 \mathrm{~mm}$ in an average of $65.2 \mathrm{~mm}$ was registered.

This data variability justifies the need for measuring $\mathrm{P}$ in replicates, as carried out. Reichardt et al. (1995) discussed the problem of rainfall variability using the city of Piracicaba as an example, and demonstrated that spatial variability has to be taken into consideration and rainfall has to be measured as close as possible to the experimental area, as it was made in this study, especially for short time periods (e.g. 14 days). During the whole agricultural year, balances 1 to 26, the total amount of rainfall was a little higher than $1,257 \mathrm{~mm}$, the historic rainfall average for the region, revealing that the year under study was within ordinary, average rainfall parameters.

\section{Irrigation (I)}

The dry, winter period extends from July to September in Piracicaba, and during this period, coffee plants are subject to water deficit. High amount of leaves fall from plants as physiological response. At the end of this period, rain triggers blossoming and continued water deficit can affect flower setting, making irrigation necessary. Because at the beginning of the experiment $(\mathrm{DAB}=0)$ the coffee plants were under strong water deficit, even after a small rainfall (4.1 $\mathrm{mm}$ ), irrigation was applied (Table 2). The variability 
of this irrigation was even greater than that of the rainfall $(\mathrm{CV}=35.1 \%)$. The irrigation system was set to apply $30 \mathrm{~mm}$ water depth, a very different value from data shown in Table 2. During the following winter (2004), another additional irrigation was needed during water balance 26 . At this time, the variability $\mathrm{CV}$ $=41.7 \%$.

Irrigations practices were mandatory to relieve the coffee crop from incident water stress. Despite difficulties, the total amount of irrigation was very small in comparison to the total amount of rainfall, and the irrigation variability affected only the estimates of two water balances -1 and 26 .

\section{Actual Evapotranspiration (ER)}

Data on ER', s(ER'), CV, ET, $\mathrm{K}_{\mathrm{C}}, \mathrm{ET}_{\mathrm{C}}$, the evapotranspiration corrected by drainage $E R$, and $Q_{L}$, are presented in Table 3. Water balances 5 to 22 were chosen to estimate $\mathrm{K}_{\mathrm{C}}$ through the relation $\mathrm{ER} / \mathrm{ET}_{0}$. During these balances, soil water storage $\mathrm{S}_{\mathrm{L}}$ was high

Table 1 - Rainfall at the five replicates, average $(\bar{P})$, standard deviations [s(P)], coefficients of variation $(\mathrm{CV})$, and rainfall at the automatic meteorological station (Ps) of each period (DAB = days after beginning).

\begin{tabular}{|c|c|c|c|c|c|c|c|c|c|c|c|}
\hline \multirow{2}{*}{ Balance } & \multirow{2}{*}{ Period } & \multirow{2}{*}{ DAB } & \multicolumn{9}{|c|}{ Rainfalll ( P ) } \\
\hline & & & 1 & 2 & 3 & 4 & 5 & $\bar{P}$ & $\mathrm{~s}(\mathrm{P})$ & $\mathrm{CV}$ & Ps \\
\hline & & & $-\cdots$ & -- & 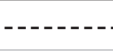 & $\mathrm{mm}$ & 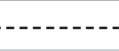 &  & -- & $\%$ & $\mathrm{~mm}$ \\
\hline 1 & $09 / 01$ to $09 / 15$ & $0 \_14$ & 4.0 & 4.2 & 4.3 & 4.2 & 4.0 & 4.1 & 0.1 & 3.2 & 5.2 \\
\hline 2 & $09 / 15$ to $09 / 29$ & $14 \_28$ & 5.8 & 5.8 & 6.4 & 4.8 & 6.2 & 5.8 & 0.6 & 10.6 & 1.2 \\
\hline 3 & $09 / 29$ to $10 / 13$ & $28 \_42$ & 79.0 & 75.4 & 80.6 & 78.0 & 75.9 & 77.8 & 2.2 & 2.8 & 84.2 \\
\hline 4 & $10 / 13$ to $10 / 27$ & $42 \_56$ & 18.2 & 18.1 & 18.2 & 17.6 & 17.5 & 17.9 & 0.3 & 1.9 & 1.9 \\
\hline 5 & $10 / 27$ to $11 / 10$ & $56 \_70$ & 25.4 & 24.9 & 26.3 & 24.5 & 25.5 & 25.3 & 0.7 & 2.7 & 46.5 \\
\hline 6 & $11 / 10$ to $11 / 24$ & $70 \_84$ & 75.7 & 74.2 & 78.7 & 74.2 & 72.5 & 75.1 & 2.3 & 3.1 & 83.0 \\
\hline 7 & $11 / 24$ to $12 / 08$ & 84_98 & 93.9 & 88.9 & 91.8 & 87.4 & 86.7 & 89.7 & 3.0 & 3.4 & 90.6 \\
\hline 8 & $12 / 08$ to $12 / 22$ & $98 \_112$ & 51.0 & 49.8 & 49.3 & 48.5 & 48.0 & 49.3 & 1.2 & 2.4 & 49.4 \\
\hline 9 & $12 / 22$ to $01 / 05$ & $112 \_126$ & 89.2 & 86.5 & 85.1 & 84.4 & 82.8 & 85.6 & 2.4 & 2.8 & 89.8 \\
\hline 10 & $01 / 05$ to $01 / 19$ & $126 \_140$ & 52.4 & 51.1 & 50.5 & 49.6 & 49.3 & 50.6 & 1.2 & 2.5 & 52.7 \\
\hline 11 & $01 / 19$ to $02 / 02$ & $140 \_154$ & 173.7 & 168.4 & 165.7 & 166.7 & 164.2 & 167.7 & 3.7 & 2.2 & 170.7 \\
\hline 12 & $02 / 02$ to $02 / 16$ & $154 \_168$ & 73.9 & 71.4 & 69.1 & 67.9 & 66.9 & 69.8 & 2.8 & 4.0 & 69.4 \\
\hline 13 & $02 / 16$ to $03 / 01$ & $168 \_182$ & 156.6 & 156.3 & 153.7 & 149.2 & 148.8 & 152.9 & 3.7 & 2.5 & 143.4 \\
\hline 14 & $03 / 01$ to $03 / 15$ & 182_196 & 75.9 & 74.8 & 72.2 & 71.4 & 71.2 & 73.1 & 2.1 & 2.9 & 74.8 \\
\hline 15 & $03 / 15$ to $03 / 29$ & 196_210 & 14.4 & 14.4 & 14.0 & 13.8 & 13.2 & 14.0 & 0.5 & 3.6 & 15.0 \\
\hline 16 & $03 / 29$ to $04 / 12$ & 210_224 & 59.4 & 78.6 & 62.2 & 65.0 & 61.0 & 65.2 & 7.7 & 11.9 & 46.6 \\
\hline 17 & $04 / 12$ to $04 / 26$ & 224_238 & 54.7 & 53.6 & 51.8 & 50.9 & 50.7 & 52.3 & 1.7 & 3.3 & 56.8 \\
\hline 18 & $04 / 26$ to $05 / 10$ & 238_252 & 23.9 & 24.1 & 22.9 & 22.3 & 22.7 & 23.2 & 0.8 & 3.4 & 28.7 \\
\hline 19 & $05 / 10$ to $05 / 24$ & $252 \_266$ & 27.4 & 27.2 & 25.1 & 23.9 & 24.1 & 25.5 & 1.7 & 6.5 & 28.8 \\
\hline 20 & $05 / 24$ to $06 / 07$ & 266_280 & 105.5 & 104.5 & 101.1 & 98.5 & 97.7 & 101.5 & 3.5 & 3.4 & 103.2 \\
\hline 21 & $06 / 07$ to $06 / 21$ & $280 \_294$ & 7.6 & 8.0 & 7.1 & 6.7 & 6.5 & 7.2 & 0.6 & 8.7 & 10.0 \\
\hline 22 & $06 / 21$ to $07 / 05$ & 294_308 & 2.4 & 2.0 & 1.8 & 1.6 & 1.6 & 1.9 & 0.3 & 17.8 & 2.2 \\
\hline 23 & $07 / 05$ to $07 / 19$ & $308 \_322$ & 33.2 & 33.1 & 32.5 & 32.2 & 32.3 & 32.7 & 0.5 & 1.4 & 43.6 \\
\hline 24 & $07 / 19$ to $08 / 02$ & $322 \_336$ & 46.8 & 45.4 & 43.9 & 43.6 & 43.1 & 44.6 & 1.5 & 3.4 & 44.9 \\
\hline 25 & $08 / 02$ to $08 / 16$ & $336 \_350$ & 0.0 & 0.0 & 0.0 & 0.0 & 0.0 & 0.0 & 0.0 & 0.0 & 0.3 \\
\hline 26 & $08 / 16$ to $08 / 30$ & $350 \_364$ & 0.0 & 0.0 & 0.0 & 0.0 & 0.0 & 0.0 & 0.0 & 0.0 & 0.0 \\
\hline Sum & $09 / 01$ to $08 / 30$ & $0 \_364$ & 1350.0 & 1340.7 & 1314.3 & 1286.9 & 1272.4 & 1312.9 & 33.4 & 2.5 & 1342.9 \\
\hline
\end{tabular}

Table 2 - Irrigation at the five replicates, average $(\bar{I})$, standard deviations $\mathrm{s}(\mathrm{I})$, and coefficients of variation $(\mathrm{CV})$. (DAB $=$ days after beginning).

\begin{tabular}{|c|c|c|c|c|c|c|c|c|c|c|}
\hline \multirow{2}{*}{ Balance } & \multirow{2}{*}{ Period } & \multirow{2}{*}{$\mathrm{DAB}$} & \multicolumn{8}{|c|}{ Irrigation $(\mathrm{mm})$} \\
\hline & & & 1 & 2 & 3 & 4 & 5 & $\bar{I}$ & $\mathrm{~s}(\mathrm{I})$ & $\mathrm{CV}$ \\
\hline & & & $-\cdots--$ & $\cdots$ & $\cdots-\cdots$ & $\mathrm{mm}$ & $\ldots$ & $x$ & $\ldots$ & $\%$ \\
\hline 1 & $09 / 01$ a $09 / 15$ & $0 \_14$ & 46.2 & 30.9 & 47.4 & 22.6 & 23.7 & 34.2 & 12.0 & 35.1 \\
\hline 26 & $08 / 16$ a $08 / 30$ & $350 \_364$ & 47.7 & 44.2 & 41.6 & 9.8 & 44.1 & 37.5 & 15.6 & 41.7 \\
\hline
\end{tabular}


Table 3 - Average actual evapotranspiration $\left(\overline{E R^{\prime}}\right)$, its standard deviation [s(ER') calculated through equation 03], reference evapotranspiration $\left(\mathrm{ET}_{0}\right)$, crop coefficient $\left(\mathrm{K}_{\mathrm{C}}\right)$, potential evapotranspiration $\left(\mathrm{ET}_{\mathrm{C}}\right)$, ER and the drainage below root zone $\left(\mathrm{Q}_{\mathrm{L}}\right)$ for each period. ( $\mathrm{DAB}=$ days after beginning).

\begin{tabular}{|c|c|c|c|c|c|c|c|c|c|}
\hline Balance & $\mathrm{DAB}$ & $\overline{E R^{\prime}}$ & $\mathrm{s}\left(\mathrm{ER}^{\prime}\right)$ & $\mathrm{CV}$ & $E T_{0}$ & $\mathrm{~K}_{\mathrm{C}}$ & $E T_{c}$ & ER & $\overline{Q_{L}}$ \\
\hline & & $\mathrm{mm}$ & & $\%$ & $\mathrm{~mm}$ & & -...--. & --- mm -. & - \\
\hline 1 & $0 \_14$ & -26.1 & 33.65 & 129.0 & -45.9 & 1.1 & -50.1 & -26.1 & 0.0 \\
\hline 2 & $14 \_28$ & -11.9 & 29.92 & 250.9 & -56.0 & 1.1 & -61.2 & -11.9 & 0.0 \\
\hline 3 & $28 \_42$ & -50.9 & 31.25 & 61.3 & -53.9 & 1.1 & -58.9 & -50.9 & 0.0 \\
\hline 4 & $42 \quad 56$ & -24.8 & 32.00 & 129.1 & -65.4 & 1.1 & -71.5 & -24.8 & 0.0 \\
\hline 5 & $56 \_70$ & -33.1 & 33.19 & 100.3 & -47.5 & 0.7 & -33.1 & -33.1 & 0.0 \\
\hline 6 & $70 \_84$ & -62.3 & 32.90 & 52.8 & -60.3 & 1.0 & -62.3 & -62.3 & 0.0 \\
\hline 7 & 84_98 & -72.0 & 30.74 & 42.7 & -50.5 & 1.4 & -72.0 & -72.0 & 0.0 \\
\hline 8 & $98 \_112$ & -57.5 & 31.10 & 54.1 & -62.4 & 0.9 & -57.5 & -57.5 & 0.0 \\
\hline 9 & $112 \_126$ & -68.1 & 33.87 & 49.7 & -57.5 & 1.2 & -68.1 & -68.1 & 0.0 \\
\hline 10 & $126 \_140$ & -52.2 & 33.28 & 63.7 & -63.2 & 0.8 & -52.2 & -52.2 & 0.0 \\
\hline 11 & $140 \_154$ & -97.4 & 33.95 & 34.9 & -39.3 & 1.1 & -42.9 & -42.9 & -54.4 \\
\hline 12 & 154_168 & -95.5 & 34.66 & 36.3 & -62.0 & 1.5 & -95.5 & -95.5 & 0.0 \\
\hline 13 & $168 \_182$ & -130.6 & 35.80 & 27.4 & -46.8 & 1.1 & -51.2 & -51.2 & -79.4 \\
\hline 14 & $182 \_196$ & -89.3 & 36.28 & 40.6 & -52.3 & 1.7 & -89.3 & -89.3 & 0.0 \\
\hline 15 & $196 \_210$ & -62.4 & 33.95 & 54.4 & -55.3 & 1.1 & -62.4 & -62.4 & 0.0 \\
\hline 16 & $210 \_224$ & -64.2 & 33.61 & 52.4 & -47.7 & 1.3 & -64.2 & -64.2 & 0.0 \\
\hline 17 & $224 \_238$ & -51.7 & 32.31 & 62.5 & -36.1 & 1.4 & -51.7 & -51.7 & 0.0 \\
\hline 18 & $238 \_252$ & -29.6 & 33.03 & 111.6 & -35.6 & 0.8 & -29.6 & -29.6 & 0.0 \\
\hline 19 & $252 \_266$ & -25.6 & 32.92 & 128.8 & -24.4 & 1.0 & -25.6 & -25.6 & 0.0 \\
\hline 20 & $266 \_280$ & -46.8 & 30.75 & 65.6 & -23.4 & 1.1 & -25.6 & -25.6 & -21.3 \\
\hline 21 & $280 \_294$ & -19.6 & 31.51 & 160.5 & -29.9 & 0.7 & -19.6 & -19.6 & 0.0 \\
\hline 22 & $294 \_308$ & -21.9 & 33.59 & 153.2 & -35.4 & 0.6 & -21.9 & -21.9 & 0.0 \\
\hline 23 & $308 \_322$ & -6.6 & 31.13 & 469.1 & -27.7 & 1.1 & -30.2 & -6.6 & 0.0 \\
\hline 24 & $322 \_336$ & -57.5 & 30.00 & 52.2 & -35.7 & 1.1 & -39.0 & -39.0 & -18.5 \\
\hline 25 & $336 \_350$ & -11.4 & 30.48 & 266.5 & -45.1 & 1.1 & -49.3 & -11.4 & 0.0 \\
\hline 26 & $350 \_364$ & -46.1 & 30.26 & 65.7 & -46.7 & 1.1 & -51.0 & -46.1 & 0.0 \\
\hline 126 & $0 \overline{364}$ & -1315.3 & - & - & -1206.0 & 1.1 & -1318.3 & -1141.7 & -173.6 \\
\hline
\end{tabular}

enough to elicit assuming that plants had no restriction to soil water, and that differences between ER and $\mathrm{ET}_{0}$ resulted from differences in plant architecture and percent of crop cover. Exception has to be made to balances 11,13 and 20, during which drainage $Q_{L}$ occurred. The variability of $K_{C}$ is large, ranging from 0.6 to 1.7 , with an average of 1.1 , standard deviation 0.3 , and $\mathrm{CV}=31.2 \%$. To complete the $\mathrm{K}_{\mathrm{C}}$ column on Table 3 , the average $\mathrm{K}_{\mathrm{C}}$ was considered for the water balances under water deficit and with drainage.

The highest ER value $\left(6.8 \mathrm{~mm} \mathrm{day}^{-1}\right)$ was obtained in balance 12, a coherent value for February in the region. The lowest values $(0.9,0.5$, and $0.8 \mathrm{~mm}$ day $^{-1}$, respectively) occurred on balances 2, 23, and 25 . During these periods, coffee plants were under water deficit and, consequently, losing leaves.

Table 4 presents the calculation of the standard deviation $s\left(E R^{\prime}\right)$ of the actual evapotranspiration, cal- culated through error propagation since this component was obtained as an unknown in equation (2). From this table it can be seen that the greatest contribution to comes from $S_{L}$ measurements. Although their CVs are relatively low (Table 5), the magnitudes of the standard deviations of $S_{L}$ are much greater in relation to those of the other components, giving a large contribution to. The use of $\Delta S_{L}$, which has a much lower magnitude, does not improve the calculations since $s\left(\Delta S_{L}\right)$ involves $s\left(S_{L i}\right)$ and $s\left(S_{L f}\right)$. As a result $s\left(E R^{\prime}\right)$ is very large in relation to its average ER', indicated by the high CVs presented in Table 3. They varied from $27.4 \%$ to $469.1 \%$, showing a great uncertainty in measuring actual evapotranspiration from water balances. Most of the high CVs correspond to wet periods, when ER was close to ETc, periods during which aerodynamic models like the combined methods of Penman, Slatyer \& Mcllroy, and Penman-Monteith (Pereira et al., 1997), yield much better estimatives. Therefore, it 
Table 4 - Estimation of the standard deviation s(ER') of the actual evapotranspiration ER', using error propagation (equation 03 ), all in mm. (DAB = days after beginning).

\begin{tabular}{llllllll}
\hline Balance & $\mathrm{DAB}$ & $\mathrm{s}(\mathrm{P})$ & $\mathrm{s}(\mathrm{I})$ & $\mathrm{s}\left(\mathrm{S}_{\mathrm{Lf}}\right)$ & $\mathrm{s}\left(\mathrm{S}_{\mathrm{L}}\right)$ & $\mathrm{s}(\mathrm{RO})$ & $\mathrm{s}(\mathrm{ER})$ \\
\hline 1 & $0 \_$14 & 0.1 & 12.0 & 20.7 & 23.7 & 0.0 & 33.6 \\
2 & $14 \_28$ & 0.6 & 0.0 & 21.6 & 20.7 & 0.0 & 29.9 \\
3 & $28 \_42$ & 2.2 & 0.0 & 22.5 & 21.6 & 0.3 & 31.2 \\
4 & $42 \_56$ & 0.3 & 0.0 & 22.8 & 22.5 & 0.0 & 32.0 \\
5 & $56 \_70$ & 0.7 & 0.0 & 24.1 & 22.8 & 0.0 & 33.2 \\
6 & $70 \_84$ & 2.3 & 0.0 & 22.3 & 24.1 & 0.4 & 32.9 \\
7 & $84 \_98$ & 3.0 & 0.0 & 21.0 & 22.3 & 0.3 & 30.7 \\
8 & $98 \_112$ & 1.2 & 0.0 & 22.9 & 21.0 & 0.0 & 31.1 \\
9 & $112 \_126$ & 2.4 & 0.0 & 24.8 & 22.9 & 0.8 & 33.9 \\
10 & $126 \_140$ & 1.2 & 0.0 & 22.1 & 24.8 & 0.1 & 33.3 \\
11 & $140 \_154$ & 3.7 & 0.0 & 25.5 & 22.1 & 0.7 & 33.9 \\
12 & $154 \_168$ & 2.8 & 0.0 & 23.3 & 25.5 & 0.4 & 34.7 \\
13 & $168 \_182$ & 3.7 & 0.0 & 26.9 & 23.3 & 1.1 & 35.8 \\
14 & $182 \_196$ & 2.1 & 0.0 & 24.3 & 26.9 & 0.7 & 36.3 \\
15 & $196 \_210$ & 0.5 & 0.0 & 23.7 & 24.3 & 0.0 & 34.0 \\
16 & $210 \_224$ & 7.7 & 0.0 & 22.5 & 23.7 & 0.3 & 33.6 \\
17 & $224 \_238$ & 1.7 & 0.0 & 23.1 & 22.5 & 0.1 & 32.3 \\
18 & $238 \_252$ & 0.8 & 0.0 & 23.6 & 23.1 & 0.1 & 33.0 \\
19 & $252 \_266$ & 1.7 & 0.0 & 22.9 & 23.6 & 0.0 & 32.9 \\
20 & $266 \_280$ & 3.5 & 0.0 & 20.2 & 22.9 & 1.1 & 30.7 \\
21 & $280 \_294$ & 0.6 & 0.0 & 24.2 & 20.2 & 0.0 & 31.5 \\
22 & $294 \_308$ & 0.3 & 0.0 & 23.3 & 24.2 & 0.0 & 33.6 \\
23 & $308 \_322$ & 0.5 & 0.0 & 20.6 & 23.3 & 0.1 & 31.1 \\
24 & $322 \_336$ & 1.5 & 0.0 & 21.7 & 20.6 & 0.0 & 30.0 \\
25 & $336 \_350$ & 0.0 & 0.0 & 21.4 & 21.7 & 0.0 & 30.5 \\
26 & $350 \_364$ & 0.0 & 15.6 & 14.7 & 21.4 & 0.7 & 30.3 \\
\hline
\end{tabular}

is not recommended to estimate ER through water balances. That does not low the value of water balance techniques, since they are useful in many water management practices, since they reflect in space and time, the water availability to the crop.

\section{Soil Water Storage $S_{L_{i}}\left(t_{i}\right)$}

Variability of the soil water storage $\left(\mathrm{S}_{\mathrm{L}}\right)$ calculated through the trapezoidal rule (equation 4) from soil water content $(\theta)$ data collected by the neutron probe is shown in Table 5. The CVs are relatively low and very consistent. Since three access tubes were placed in each plot, each average $\overline{S_{L}}$ is the result of 15 measurements, what should be a good estimative of the soil water situation at the moment $t_{i}$. Advantage of neutron probes over classical methodologies is that they allow measurements along time at exactly the same position. This explains the homogeneity of the CVs. The variability of the data shown in Table 5 depicts accurately soil water variability of the experimental field. Using the conventional methods, such as gauge sampling, it would not be possible to measure $\theta$ always at the same positions, and this would exceed- ingly increase data variability and would require a much larger experimental area, once samplings are destructive.

The lowest value of $\mathrm{S}_{\mathrm{Lmin}}(245.2 \mathrm{~mm})$ was registered in Sep.01.2003, corresponding to a severe water stress condition, but still not high enough to stop crop growing. This value could be taken as a "field wilting point" in order to calculate a practical value of the available water holding capacity of the $0-1.0 \mathrm{~m}$ layer. For the field capacity one could take the value of $\mathrm{S}_{\mathrm{Lmax}}$ for Mar.01.2004, measured after a long rainfall period and with no subsequent deep drainage (Table 7). Considering these extreme values, the available water capacity of this soil profile $\left(\mathrm{S}_{\mathrm{Lmax}}-\mathrm{S}_{\mathrm{Lmin}}\right)$ is $120 \mathrm{~mm}$, which represents the maximum possible variation of $\mathrm{S}_{\mathrm{L}}$ in this crop down to the depth of $1.0 \mathrm{~m}$ for this particular soil.

\section{Runoff (RO)}

The runoff was very small in relation to the other components $(1.7 \%$ in relation to rainfall), presented large variability, not appearing in all plots and in an inconsistent way. This means that the coffee 
Table 5 - Initial soil water storage $\mathrm{S}_{\mathrm{L}}\left(\mathrm{t}_{\mathrm{i}}\right)$ at each of the five replicates, average $\left(\overline{S_{L}}\right)$, standard deviations $\mathrm{s}\left(\mathrm{S}_{\mathrm{L}}\right)$, and coefficients of variation $(\mathrm{CV})$ of each period. (DAB = days after beginning).

\begin{tabular}{|c|c|c|c|c|c|c|c|c|c|c|}
\hline \multirow{2}{*}{ Balance } & \multirow{2}{*}{ Date } & \multirow{2}{*}{ DAB } & \multicolumn{5}{|c|}{$\mathrm{S}_{\mathrm{I}}$} & \multirow{2}{*}{$\overline{S_{L}}$} & \multirow{2}{*}{$\mathrm{s}\left(\mathrm{S}_{\mathrm{L}}\right)$} & \multirow{2}{*}{$\mathrm{CV}$} \\
\hline & & & 1 & 2 & 3 & 4 & 5 & & & \\
\hline & & & ------- & -..-. & 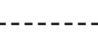 & $-\mathrm{mm}-$ & --.--. & - - & -..-.-. & $\%$ \\
\hline 1 & $09 / 01 / 03$ & 0 & 250.2 & 260.8 & 203.4 & 254.6 & 257.2 & 245.2 & 23.7 & 9.7 \\
\hline 2 & $09 / 15 / 03$ & 14 & 261.0 & 271.1 & 221.0 & 265.6 & 268.3 & 257.4 & 20.7 & 8.0 \\
\hline 3 & $09 / 29 / 03$ & 28 & 255.9 & 265.6 & 213.1 & 259.3 & 262.4 & 251.3 & 21.6 & 8.6 \\
\hline 4 & $10 / 13 / 03$ & 42 & 272.3 & 284.5 & 242.8 & 303.0 & 286.9 & 277.9 & 22.5 & 8.1 \\
\hline 5 & $10 / 27 / 03$ & 56 & 269.9 & 280.3 & 232.8 & 292.2 & 279.9 & 271.0 & 22.8 & 8.4 \\
\hline 6 & $11 / 10 / 03$ & 70 & 263.2 & 276.0 & 221.5 & 278.7 & 276.8 & 263.3 & 24.1 & 9.2 \\
\hline 7 & $11 / 24 / 03$ & 84 & 273.0 & 287.4 & 238.7 & 296.3 & 282.5 & 275.6 & 22.3 & 8.1 \\
\hline 8 & $12 / 08 / 03$ & 98 & 286.3 & 306.7 & 262.3 & 317.2 & 293.1 & 293.1 & 21.0 & 7.2 \\
\hline 9 & $12 / 22 / 03$ & 112 & 277.9 & 299.8 & 249.8 & 309.2 & 288.0 & 284.9 & 22.9 & 8.0 \\
\hline 10 & $01 / 05 / 04$ & 126 & 288.3 & 312.9 & 271.4 & 336.9 & 299.9 & 301.9 & 24.8 & 8.2 \\
\hline 11 & $01 / 19 / 04$ & 140 & 288.0 & 311.4 & 270.2 & 328.0 & 303.2 & 300.2 & 22.1 & 7.4 \\
\hline 12 & $02 / 02 / 04$ & 154 & 380.0 & 380.2 & 324.5 & 384.3 & 380.6 & 369.9 & 25.5 & 6.9 \\
\hline 13 & $02 / 16 / 04$ & 168 & 352.1 & 354.8 & 302.6 & 359.5 & 350.8 & 344.0 & 23.3 & 6.8 \\
\hline 14 & $03 / 01 / 04$ & 182 & 375.4 & 382.3 & 317.4 & 375.2 & 375.3 & 365.1 & 26.9 & 7.4 \\
\hline 15 & $03 / 15 / 04$ & 196 & 356.2 & 364.1 & 305.4 & 359.2 & 357.7 & 348.5 & 24.3 & 7.0 \\
\hline 16 & $03 / 29 / 04$ & 210 & 310.5 & 314.4 & 258.0 & 311.5 & 306.0 & 300.1 & 23.7 & 7.9 \\
\hline 17 & $04 / 12 / 04$ & 224 & 304.5 & 317.2 & 261.9 & 315.4 & 305.2 & 300.8 & 22.5 & 7.5 \\
\hline 18 & $04 / 26 / 04$ & 238 & 305.0 & 313.3 & 261.0 & 318.2 & 309.2 & 301.3 & 23.1 & 7.7 \\
\hline 19 & $05 / 10 / 04$ & 252 & 301.0 & 306.4 & 253.0 & 308.7 & 305.4 & 294.9 & 23.6 & 8.0 \\
\hline 20 & $05 / 24 / 04$ & 266 & 300.2 & 304.8 & 254.3 & 306.1 & 308.8 & 294.8 & 22.9 & 7.8 \\
\hline 21 & $06 / 07 / 04$ & 280 & 360.1 & 359.9 & 312.8 & 356.2 & 354.3 & 348.7 & 20.2 & 5.8 \\
\hline 22 & $06 / 21 / 04$ & 294 & 348.4 & 348.7 & 293.3 & 342.0 & 348.7 & 336.2 & 24.2 & 7.2 \\
\hline 23 & $07 / 05 / 04$ & 308 & 327.7 & 327.7 & 274.8 & 321.6 & 329.2 & 316.2 & 23.3 & 7.4 \\
\hline 24 & $07 / 19 / 04$ & 322 & 350.7 & 345.4 & 306.0 & 353.7 & 355.3 & 342.2 & 20.6 & 6.0 \\
\hline 25 & $08 / 02 / 04$ & 336 & 341.4 & 334.6 & 290.7 & 337.9 & 341.7 & 329.3 & 21.7 & 6.6 \\
\hline 26 & $08 / 16 / 04$ & 350 & 334.1 & 324.3 & 280.4 & 322.9 & 327.4 & 317.8 & 21.4 & 6.7 \\
\hline 27 & $08 / 30 / 04$ & 364 & 323.4 & 310.3 & 284.2 & 313.6 & 313.0 & 308.9 & 14.7 & 4.8 \\
\hline
\end{tabular}

crop planted on a $10 \%$ slope along contour-lines was adequate for runoff and, consequently, erosion control.

The high CVs presented in Table 6 demand careful analysis. The presence of many null values may indicate that this variable probably does not follow the normal distribution and with very low mean values, $\mathrm{CVs}$ tend to increase by definition, even when the variable is correctly measured. Anyway, the absolute values of RO were very small and affected very little the establishment of water balances.

\section{Water Balances}

Table 7 summarizes all water balance components.

The historic average of annual rainfall in Piracicaba is $1,257 \mathrm{~mm}$, which shows that the considered year (Sept.2003/Sept.2004) was slightly more rainy than normal. The irrigation in this region is not necessary for most perennial crops, coffee included.
The amount of irrigation water applied $(71.6 \mathrm{~mm})$ aimed solely to prevent blooming damage during water stress periods. When water inputs $(\mathrm{P}+\mathrm{I})$ is considered, RO represents only $0.4 \%$ of the balance, that is, this component was not significant under the conditions in which the evaluations were carried out. There was a tendency of increasing RO with increasing P. This fact is expected, but is very hard to be forecasted once RO depends more on rain intensity than on total amount of water. Since the analyzed period did not deviate significantly from the ordinary local rainfall intensities, it is expected that the adopted crop management procedures limit this component to minimum values, e.g. those shown in Table 6.

The drainage below the depth $\mathrm{z}=1.0 \mathrm{~m}$ was $12.5 \%$ of the balance, which can be more significant in wetter years. In terms of $\mathrm{N}$ leaching, a reflex of drainage, splitting the plots' fertilization was adequate 
Table 6 - Runoff (RO) at each of the five replicates, average ( $\overline{R O}$ ), standard deviations (SD), and coefficients of variation $(\mathrm{CV})$ from each period. (DAB = days after beginning).

\begin{tabular}{|c|c|c|c|c|c|c|c|c|c|c|}
\hline \multirow{2}{*}{ Balance } & \multirow{2}{*}{ Period } & \multirow{2}{*}{ DAB } & \multicolumn{5}{|c|}{ RO } & \multirow{2}{*}{$\overline{R O}$} & \multirow{2}{*}{$\mathrm{s}(\mathrm{RO})$} & \multirow{2}{*}{$\mathrm{CV}$} \\
\hline & & & 1 & 2 & 3 & 4 & 5 & & & \\
\hline & & & ---- & --- & $-\cdots$ & m --- & - - & - - & & $\%$ \\
\hline 1 & $09 / 01$ to $09 / 15$ & $0 \_14$ & - & - & - & - & - & - & - & - \\
\hline 2 & $09 / 15$ to $09 / 29$ & $14 \_28$ & - & - & - & - & - & - & - & - \\
\hline 3 & $09 / 29$ to $10 / 13$ & $28 \_42$ & 0.0 & 0.0 & 0.4 & 0.6 & 0.1 & 0.2 & 0.3 & 118.9 \\
\hline 4 & $10 / 13$ to $10 / 27$ & $42 \_56$ & 0.0 & 0.0 & 0.0 & 0.0 & 0.1 & 0.0 & 0.0 & 223.6 \\
\hline 5 & $10 / 27$ to $11 / 10$ & $56 \_70$ & - & - & - & - & - & - & - & - \\
\hline 6 & $11 / 10$ to $11 / 24$ & $70 \_84$ & 0.0 & 0.0 & 0.6 & 0.8 & 0.5 & 0.4 & 0.4 & 94.3 \\
\hline 7 & $11 / 24$ to $12 / 08$ & 84_98 & 0.0 & 0.0 & 0.2 & 0.0 & 0.7 & 0.2 & 0.3 & 173.2 \\
\hline 8 & $12 / 08$ to $12 / 22$ & $98 \_112$ & - & - & - & - & - & - & - & - \\
\hline 9 & $12 / 22$ to $01 / 05$ & $112 \_126$ & 0.0 & 0.0 & 0.7 & 1.8 & 0.1 & 0.5 & 0.8 & 149.6 \\
\hline 10 & $01 / 05$ to $01 / 19$ & $126 \_140$ & 0.0 & 0.0 & 0.1 & 0.3 & 0.0 & 0.1 & 0.1 & 138.3 \\
\hline 11 & $01 / 19$ to $02 / 02$ & $140 \_154$ & 0.0 & 0.0 & 1.4 & 1.4 & 0.1 & 0.6 & 0.7 & 125.6 \\
\hline 12 & $02 / 02$ to $02 / 16$ & 154_168 & 0.0 & 0.0 & 0.4 & 0.9 & 0.0 & 0.3 & 0.4 & 152.7 \\
\hline 13 & $02 / 16$ to $03 / 01$ & $168 \_182$ & 3.0 & 0.5 & 1.1 & 1.3 & 0.0 & 1.2 & 1.1 & 96.0 \\
\hline 14 & $03 / 01$ to $03 / 15$ & 182_196 & 0.0 & 0.0 & 0.6 & 1.5 & 0.0 & 0.4 & 0.7 & 155.1 \\
\hline 15 & $03 / 15$ to $03 / 29$ & 196_210 & - & - & - & - & - & - & - & - \\
\hline 16 & $03 / 29$ to $04 / 12$ & 210_224 & 0.6 & 0.2 & 0.6 & 0.0 & 0.0 & 0.3 & 0.3 & 110.6 \\
\hline 17 & $04 / 12$ to $04 / 26$ & $224 \_238$ & 0.0 & 0.0 & 0.1 & 0.3 & 0.0 & 0.1 & 0.1 & 158.8 \\
\hline 18 & $04 / 26$ to $05 / 10$ & $238 \_252$ & 0.0 & 0.0 & 0.1 & 0.2 & 0.0 & 0.1 & 0.1 & 142.6 \\
\hline 19 & $05 / 10$ to $05 / 24$ & $252 \_266$ & 0.0 & 0.0 & 0.0 & 0.0 & 0.0 & 0.0 & 0.0 & 223.6 \\
\hline 20 & $05 / 24$ to $06 / 07$ & 266_280 & 0.0 & 0.0 & 2.2 & 1.9 & 0.0 & 0.8 & 1.1 & 136.6 \\
\hline 21 & $06 / 07$ to $06 / 21$ & 280_294 & - & - & - & - & - & - & - & - \\
\hline 22 & $06 / 21$ to $07 / 05$ & 294_308 & - & - & - & - & - & - & - & - \\
\hline 23 & $07 / 05$ to $07 / 19$ & $308 \_322$ & 0.0 & 0.0 & 0.2 & 0.1 & 0.0 & 0.1 & 0.1 & 127.3 \\
\hline 24 & $07 / 19$ to $08 / 02$ & $322 \_336$ & 0.0 & 0.0 & 0.0 & 0.0 & 0.0 & 0.0 & 0.0 & 156.5 \\
\hline 25 & $08 / 02$ to $08 / 16$ & $336 \_350$ & - & - & - & - & - & - & - & - \\
\hline 26 & $08 / 16$ to $08 / 30$ & $350 \_364$ & 1.5 & 0.2 & 0.0 & 0.0 & 0.0 & 0.3 & 0.7 & 189.9 \\
\hline Sum & $09 / 01$ to $08 / 30$ & $0 \_364$ & 5.1 & 1.0 & 8.7 & 11.1 & 1.6 & 5.5 & 4.4 & 80.3 \\
\hline
\end{tabular}

in relation to the water balance components. As the annual variation of $\Delta S_{L}$ should, theoretically, be small along extended periods (e.g. one year or-5.5 $\mathrm{mm}$ in this case), the remaining of the water balance is ER, and represents $82.5 \%$. In ideal situation, in which RO and $\mathrm{Q}_{\mathrm{L}}$ are null, ER would represent $100 \%$ of $(\mathrm{P}+\mathrm{I})$, that is, $\mathrm{ER}=(\mathrm{P}+\mathrm{I})$. Such condition almost happened over the studied year.

Figure 2 shows the distribution of rainfall and evapotranspiration along the year (Sept.2003/ Sept.2004). In general, the rainfall was well distributed, except for the unusual high rainfall rate during June and July (balances 20 to 24), ordinarily the driest months in the region. This exception guaranteed a good crop development. At the end of the dry season, represented by balances 1 and 2; 25 and 26, irrigation was necessary. The highest rainfall occurred during balances 11 and 13, and, as a consequence, the drainage $\left(\mathrm{Q}_{\mathrm{L}}\right)$ was $12.5 \%$ of $(\mathrm{P}+\mathrm{I})$.

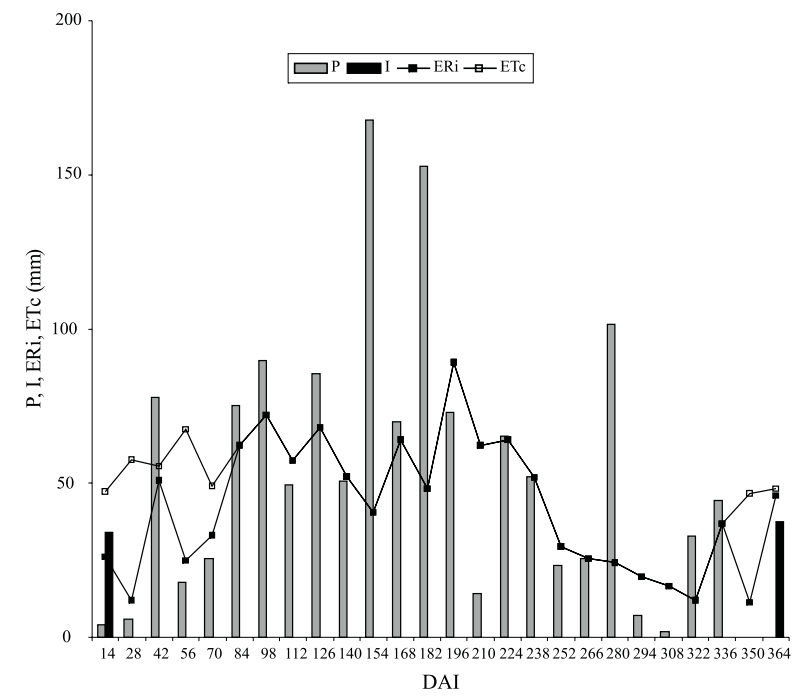

Figure 2 - Rainfall (P), irrigation (I), actual evapotranspiration (ER), and potential evapotranspiration (ETc) for all periods ( $\mathrm{DAB}=$ days after beginning). 
Table 7 - Average values of rainfall $(\bar{P})$, irrigation $(\bar{I})$, soil water storage changes $(\overline{\Delta S})$, runoff $(\overline{R O})$, drainage $\left(\overline{Q_{L}}\right)$, actual evapotranspiration $(\overline{E R})$, and potential evapotranspiration $\left(\overline{E T_{C}}\right)$, for all analyzed periods. $(\mathrm{DAB}=$ days after beginning).

\begin{tabular}{|c|c|c|c|c|c|c|c|c|c|c|}
\hline Balance & Period & $\mathrm{DAB}$ & $\bar{P}$ & $\bar{I}$ & $\overline{S_{L}}$ & $\overline{\Delta S}$ & $\overline{R O}$ & $\overline{Q_{L}}$ & $\overline{E R}$ & $\overline{E T_{C}}$ \\
\hline & & & & & & --1 & $\mathrm{~mm}$ & & & -..- \\
\hline 1 & $09 / 01$ to $09 / 15$ & $0 \_14$ & 4.1 & 34.2 & 245.2 & 12.2 & 0.0 & 0.0 & -26.1 & -50.1 \\
\hline 2 & $09 / 15$ to $09 / 29$ & $14 \_28$ & 5.8 & 0.0 & 257.4 & -6.1 & 0.0 & 0.0 & -11.9 & -61.2 \\
\hline 3 & $09 / 29$ to $10 / 13$ & $28 \_42$ & 77.8 & 0.0 & 251.3 & 26.6 & -0.2 & 0.0 & -50.9 & -58.9 \\
\hline 4 & $10 / 13$ to $10 / 27$ & $42 \_56$ & 17.9 & 0.0 & 277.9 & -6.9 & 0.0 & 0.0 & -24.8 & -71.5 \\
\hline 5 & $10 / 27$ to $11 / 10$ & $56 \_70$ & 25.3 & 0.0 & 271.0 & -7.8 & 0.0 & 0.0 & -33.1 & -33.1 \\
\hline 6 & $11 / 10$ to $11 / 24$ & $70 \_84$ & 75.1 & 0.0 & 263.3 & 12.3 & -0.4 & 0.0 & -62.3 & -62.3 \\
\hline 7 & $11 / 24$ to $12 / 08$ & 84_98 & 89.7 & 0.0 & 275.6 & 17.5 & -0.2 & 0.0 & -72.0 & -72.0 \\
\hline 8 & $12 / 08$ to $12 / 22$ & 98_112 & 49.3 & 0.0 & 293.1 & -8.2 & 0.0 & 0.0 & -57.5 & -57.5 \\
\hline 9 & $12 / 22$ to $01 / 05$ & $112 \_126$ & 85.6 & 0.0 & 284.9 & 17.0 & -0.5 & 0.0 & -68.1 & -68.1 \\
\hline 10 & $01 / 05$ to $01 / 19$ & $126 \_140$ & 50.6 & 0.0 & 301.9 & -1.7 & -0.1 & 0.0 & -52.2 & -52.2 \\
\hline 11 & $01 / 19$ to $02 / 02$ & $140 \_154$ & 167.7 & 0.0 & 300.2 & 69.8 & -0.6 & -54.4 & -42.9 & -42.9 \\
\hline 12 & $02 / 02$ to $02 / 16$ & 154_168 & 69.8 & 0.0 & 369.9 & -26.0 & -0.3 & 0.0 & -95.5 & -95.5 \\
\hline 13 & $02 / 16$ to $03 / 01$ & $168 \_182$ & 152.9 & 0.0 & 344.0 & 21.1 & -1.2 & -79.4 & -51.2 & -51.2 \\
\hline 14 & $03 / 01$ to $03 / 15$ & 182_196 & 73.1 & 0.0 & 365.1 & -16.6 & -0.4 & 0.0 & -89.3 & -89.3 \\
\hline 15 & $03 / 15$ to $03 / 29$ & $196 \_210$ & 14.0 & 0.0 & 348.5 & -48.4 & 0.0 & 0.0 & -62.4 & -62.4 \\
\hline 16 & $03 / 29$ to $04 / 12$ & 210_224 & 65.2 & 0.0 & 300.1 & 0.7 & -0.3 & 0.0 & -64.2 & -64.2 \\
\hline 17 & $04 / 12$ to $04 / 26$ & $224 \_238$ & 52.3 & 0.0 & 300.8 & 0.5 & -0.1 & 0.0 & -51.7 & -51.7 \\
\hline 18 & $04 / 26$ to $05 / 10$ & $238 \_252$ & 23.2 & 0.0 & 301.3 & -6.4 & -0.1 & 0.0 & -29.6 & -29.6 \\
\hline 19 & $05 / 10$ to $05 / 24$ & $252 \_266$ & 25.5 & 0.0 & 294.9 & -0.1 & 0.0 & 0.0 & -25.6 & -25.6 \\
\hline 20 & $05 / 24$ to $06 / 07$ & $266 \_280$ & 101.5 & 0.0 & 294.8 & 53.8 & -0.8 & -21.3 & -25.6 & -25.6 \\
\hline 21 & $06 / 07$ to $06 / 21$ & $280 \_294$ & 7.2 & 0.0 & 348.7 & -12.4 & 0.0 & 0.0 & -19.6 & -19.6 \\
\hline 22 & $06 / 21$ to $07 / 05$ & 294_308 & 1.9 & 0.0 & 336.2 & -20.0 & 0.0 & 0.0 & -21.9 & -21.9 \\
\hline 23 & $07 / 05$ to $07 / 19$ & $308 \_322$ & 32.7 & 0.0 & 316.2 & 26.0 & -0.1 & 0.0 & -6.6 & -30.2 \\
\hline 24 & $07 / 19$ to $08 / 02$ & $322 \_336$ & 44.6 & 0.0 & 342.2 & -12.9 & 0.0 & -18.5 & -39.0 & -39.0 \\
\hline 25 & $08 / 02$ to $08 / 16$ & $336 \_350$ & 0.0 & 0.0 & 329.3 & -11.4 & 0.0 & 0.0 & -11.4 & -49.3 \\
\hline 26 & $08 / 16$ to $08 / 30$ & $350 \_364$ & 0.0 & 37.5 & 317.8 & -8.9 & -0.4 & 0.0 & -46.1 & -51.0 \\
\hline Sum & $09 / 01$ to $08 / 30$ & $0 \_364$ & 1312.8 & 71.6 & 7931.6 & 63.7 & -5.5 & -173.6 & -1141.7 & -1336.1 \\
\hline
\end{tabular}

The actual evapotranspiration got closer to the maximum almost along the whole year, except for the dry periods (balances 1, 2, 4, 23, 25, and 26). During these periods, the coffee plants lost part of their leaves because the soil hydraulic conductivity was too low, limiting water flux to the plant root system which did not attend atmospheric demand.

\section{CONCLUDING REMARKS}

In areas with neighboring obstacles, the dynamics of the wind and, consequently, of the rainfall can be affected, and so measurement of the rainfall should be made with an adequate number of replicates. However, the use of data obtained at neighboring meteorological station is not recommended. In this study, an area of $0.2 \mathrm{ha}$, with trees, silo, and warehouse between 5 and $20 \mathrm{~m}$ high, and located within $100 \mathrm{~m}$, five rain-gauges apart from each other 15 to $100 \mathrm{~m}$, pre- sented CVs ranging on 1.4 to $17.8 \%$. The atmospheric demand of the coffee crop, expressed by its actual evapotranspiration, was $1141.7 \mathrm{~mm}$ per year, and was almost completely satisfied by rainfall input. In complex terrain, the water balance terms can display substantial variability. To infer a representative estimate of the actual evapotranspiration as a remainder of the water balance, knowledge of the spatial variability of the other components is therefore necessary. Because of error propagation, estimates derived from a exceedingly small set of point measurements can be substantially flawed. For the agricultural year under analysis, the soil in question presented a maximum water holding capacity of $120 \mathrm{~mm}$, which represents a backup of water for 24 days considering an average demand of $5 \mathrm{~mm} \mathrm{day}{ }^{-1}$, without considering the restrictions on water flux to the roots in drier periods. In this year, the rainfall was near to the long term average, and was enough to meet the atmospheric demand of the crop, 
with restrictions in the period of dry and cold winter, favorable for blossoming. Soils with smaller storage capacity are likely to cause water supply problems and also permit larger values of internal drainage and, consequently, leaching. Soil water storage, although measured carefully, was the component that introduced most variability and error propagation in water balance calculations. Coffee plantations in steep-sloped areas have to be made in a way that elicits good water infiltration, minimizing runoff losses and erosion process. Planting made in furrows along contour-lines reduced considerably the runoff and so erosion neared zero. In this study, carried upon a soil with average slope $10 \%$, the value runoff did not exceed $1.7 \%$ of total rainfall.

\section{ACKNOWLEDGMENT}

The authors thank FAPESP, CNPq and CAPES for finantial support and fellowships.

\section{REFERENCES}

BASANTA, M.del V. Dinâmica do nitrogênio na cultura de cana-deaçúcar em diferentes sistemas de manejo de resíduos da colheita. Piracicaba: USP/ESALQ, 2004. (Tese - Doutorado).
EMPRESA BRASILEIRA DE PESQUISA AGROPECUÁRIA. Centro Nacional de Pesquisa de Solo. Sistema brasileiro de classificação de solos. Rio de Janeiro: Embrapa Solos, 1999. 412p.

FNP CONSULTORIA \& COMÉRCIO. Agrianual 2004: Anuário da Agricultura Brasileira. São Paulo, 2004. 185p.

GREGORICH, E.G.; CARTER, M.R. Soil qualify for crop production and ecosystem health. Amsterdam: Elsevier, 1997. 456p.

MONTEITH, J.L. Principles of environmental physics. Elsevier: New York, 1973. 241p.

PEREIRA, A.R.; VILlA NOVA, N.A.; SEDIYAMA, G.C. Evapo(transpi)ração. Piracicaba: FEALQ, 1997. 183p.

PEREIRA, A.R.; ANGELOCCI, L.R.; SENTELHAS, P.C. Agrometeorologia, fundamentos e aplicações. Guaíba: Livraria e Editora Agropecuária, 2002. 478p.

REICHARDT, K.; ANGELOCCI, L.R.; BACCHI, O.O.S.; PILOTTO, J.E. Daily rainfall variability at a local scale (1,000 ha), in Piracicaba, SP, Brazil, and its implications on soil water recharge. Scientia Agricola, v.52, p.43-49, 1995.

VILLA NOVA, N.A. Dados agrometeorológicos do município de Piracicaba. Piracicaba: ESALQ/Departamento de Física e Meteorologia, 1989.

VILLAGRA, M.M.; BACCHI, O.O.S.; TUON, R.L.; REICHARDT, K. Difficulties of estimating evaporation from the water balance equation. Agricultural and Forest Meteorology, v.72, p.317-325, 1995.

Received June 08, 2005

Accepted March 02, 2006 